\title{
Corrosion Resistance of an SS 316L Alloy in Artificial Saliva in Presence of a Sparkle Fresh Toothpaste
}

\author{
Renita D'Souza, ${ }^{a, *}$ A. Chattree ${ }^{a}$ and S. Rajendran ${ }^{b}$ \\ ${ }^{a}$ Department of Chemistry, SHIATS, Allahabad, 211007, UP, India \\ ${ }^{b}$ Department of Chemistry, St Antony's College of Arts and Science for Women, Amala Annai \\ Nagar, Thamaraipadi (Post), Dindigul - 624 005, India
}

Received November 02, 2016; accepted April 15, 2017

\begin{abstract}
People are implanted with orthodontic wires made of different materials, to regulate their teeth. The various toothpastes that they use during the course of the treatment may have a corrosive effect on these materials. Hence, the main objective of this study was to evaluate the corrosion behaviour of an SS 316L alloy in artificial saliva in the presence of a sparkle fresh toothpaste. An electrochemical study has been used to investigate the corrosion behaviour of this alloy. Scanning electron microscopy (SEM) imaging gave the morphological data for the sample; however, by using X-ray spectroscopy in conjunction with SEM (EDAX), the elemental composition was determined. Further, the analysis of

the protective film formed on the metal surface was done using UV-visible absorption and fluorescence spectra. The corrosion resistance of the SS $316 \mathrm{~L}$ system in various solutions decreases in the following order: AS+ toothpaste> toothpaste>AS. For AS+

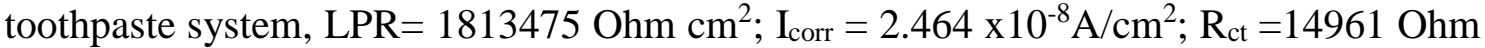
$\mathrm{cm}^{2} ; \mathrm{C}_{\mathrm{dl}}=3.4088 \times 10^{-10} \mathrm{~F} / \mathrm{cm}^{2}$ and impedance $=4.397 \mathrm{log} \mathrm{z} / \mathrm{Ohm}$. The high corrosion resistance offered by the toothpaste is due to the formation of a protective film. It confirmed that the active principles of the toothpaste ingredients have co-ordinated with the SS 316L metal ions through their polar atoms to form a complex.
\end{abstract}

Keywords: Orthodontic appliances, toothpaste, dental alloys, impedance, resistance, ingredients.

\section{Introduction}

In dentistry, precious metals and alloys often used are $\mathrm{Au}, \mathrm{Ag}, \mathrm{Pt}$ and their alloys. They possess good cast ability, ductility and resistance to corrosion [1]. The escalating cost of precious metals throughout the 20th century has been one of the primary reasons for the development of base metal alloys for dental applications. In addition, these non-precious alloys were also found to provide better mechanical properties and aesthetics for some oral applications. Due to

\footnotetext{
* Corresponding author. E-mail address: renitavinaya@yahoo.com
} 
their superior mechanical properties and lower density, certain base metal alloy systems are preferred. Stainless steels, nickel-chromium, cobalt-chromium, titanium, and nickel-titanium alloys are some of the base metal alloy systems most commonly used in dentistry of today [2].

\section{Stainless steel alloys}

Stainless steel has been successfully used in dentistry for almost a century. The first stainless steel used for implants contained $\sim 18 \mathrm{wt} \% \mathrm{Cr}$ and $\sim 8 \mathrm{wt} \% \mathrm{Ni}$, which made it stronger than steel and more resistant to corrosion. Further addition of molybdenum (Mo) has improved stainless steels (known as type 316). Afterwards, the carbon (C) content has been reduced from 0.08 to $0.03 \mathrm{wt} \%$, which improved stainless steel (named as 316L) corrosion resistance to a chloride solution $[1,3]$.

\section{Physical properties of metals}

One important criterion in metals selection is the consideration of their physical properties, such as density, melting point, specific heat, thermal conductivity, thermal expansion and corrosion. For many applications, one of the most important considerations is their deterioration by corrosion. Corrosion of metal depends on the metals composition and the corrosive media in the surrounding environment [3].

Chromium has a very strong affinity with oxygen, resulting in the creation of chromium oxide on the surface of stainless steel, when it is exposed to oxygen. Chromium oxide is a very thin layer that prevents further oxidation of stainless steel. Even if stainless steel is scratched and the chromium oxide layer is removed, a new chromium oxide layer will form and protect the remaining stainless steel beneath it. The chromium oxide layer will continue to protect stainless steel and prevent it from undergoing corrosion, as long as there is sufficient chromium present in it [4].

There are several metals and metal alloys used in dentistry and orthodontic applications. Corrosion of orthodontic appliances has been thoroughly studied [5-10]. The oral cavity represents a harsh environment for orthodontic appliances of any kind [11]. The traces of corrosion on the surfaces of metals used in any application can be formed after a period of time depending on the mouth environment [12]. The corrosion process occurs as a result either of the loss of metal ions directly into the solution or of the progressive dissolution of the surface films, as a rule oxide or sulphide [13]. Corrosion resistance is one of the important features of dental materials, because after introducing the metallic biomaterials into the human body, they are subject to a corrosive medium [14].

Orthodontic wires are recommended by the dentists to regulate the arrangement of teeth. People with these orthodontic wires have to daily brush their teeth. The toothpaste that they use may corrode the orthodontic wires in the oral environment. Hence, there is a need to investigate the influence of various toothpastes on the corrosion resistance of orthodontic wires made of many metals and alloys. The following work was undertaken to study the corrosion behaviour 
of an SS 316L alloy in artificial saliva, in the absence and presence of a sparkle fresh toothpaste.

\section{Experimental \\ Materials}

The metal specimens, namely, SS 316L, were chosen for the present study. The study was carried out in the presence of artificial saliva (AS) using a sparkle fresh toothpaste. The composition of SS 316L is $\mathrm{Cr}$ (18\%), Ni (12\%), Mo $(2.5 \%), \mathrm{C}(<0.03 \%)$ and balance is $\mathrm{Fe}$ [15]. The composition of artificial saliva in $\mathrm{g} / \mathrm{L}^{-1}$ is $\mathrm{KCl}(0.4), \mathrm{NaCl}(0.4), \mathrm{CaCl}_{2} .2 \mathrm{H}_{2} \mathrm{O}(0.906), \mathrm{NaH}_{2} \mathrm{PO}_{4} .2 \mathrm{H}_{2} \mathrm{O}$ (0.690), $\mathrm{Na}_{2} \mathrm{~S} .9 \mathrm{H}_{2} \mathrm{O}(0.005)$ and urea (1.0) [16-18].

The ingredients of the sparkle fresh toothpaste are sodium monofluorophosphate (active ingredients), calcium carbonate, carboxymethyl cellulose, glycerine, hydrated silica, sodium benzoate, sodium lauryl sulfate, sodium saccharin, sorbitol, tetra sodium pyrophosphate and water (inactive ingredients).

\section{Methods}

\section{Potentiodynamic polarization}

Polarization studies were carried out in a CHI-electrochemical workstation with impedance, model 660A. A three-electrode cell assembly was used. The working electrode used was a thin wire metal specimen. A saturated calomel electrode (SCE) was the reference electrode, and platinum was the counter electrode. IR contribution was minimized by placing the reference electrode close to the working electrode. To attain a steady state open circuit potential, a time interval of about 5 minutes was given for the working electrode. The corrosion parameters such as corrosion potential $\left(E_{\text {corr }}\right)$, corrosion current $\left(I_{\text {corr }}\right)$, Tafel slopes (anodic $=b_{\mathrm{a}}$ and cathodic $=b_{\mathrm{c}}$ ) and linear polarization resistance $(L P R)$ were calculated. During the polarization study, the scan rate $(\mathrm{V} / \mathrm{s})$ was 0.005; hold time at Ef (s) was zero and quite time (s) was 2.

\section{AC impedance measurements}

The measure of the ability of a circuit to resist the flow of electrical current is known as impedance. By applying an AC potential to an electrochemical cell and then measuring the current through the cell, the electrochemical impedance is usually measured using a small excitation signal. The instrument used for the polarization study was also used to record AC impedance spectra. The cell setup was also the same. The real part ( $\left.Z^{\prime}\right)$ and imaginary part (Z') of the cell impedance were measured in Ohms at various frequencies. Values of the charge transfer resistance $\left(R_{t}\right)$ and double layer capacitance $\left(C_{d l}\right)$ were calculated from the Nyquist plot and the impedance; log $(\mathrm{z} / \mathrm{Ohm})$ value was calculated from Bode plots. During AC, impedance spectra were recorded: the scan rate $(\mathrm{V} / \mathrm{s})$ was 0.005; hold time at $\operatorname{Ef}(\mathrm{s})$ was zero and quite time (s) was 2 . The value of charge transfer resistance $\left(\mathrm{R}_{\mathrm{t}}\right)$ and double layer capacitance $\left(\mathrm{C}_{\mathrm{dl}}\right)$ were calculated from Nyquist plot. 


$$
R_{t}=\left(R_{s}+R_{t}\right)-R_{s}
$$

(where $\mathrm{R}_{\mathrm{S}}=$ solution resistance, $\mathrm{R}_{\mathrm{t}}=$ charge transfer resistance)

$$
\mathrm{C}_{\mathrm{dl}}=\frac{1}{2 \times 3.14 \times \mathrm{R}_{\mathrm{t}} \times \mathrm{f}_{\max }}
$$

where $f_{\max }=$ frequency at maximum imaginary impedance.

\section{$U V$ - visible absorption spectra of solutions}

The possibility of the formation of a metal - inhibitor complex in a solution was examined by recording its UV-visible absorption spectra for the blank, the inhibitor and the best system solution using an Analytic Jena Specord S-100, UV -visible spectrometer.

\section{Fluorescence spectroscopy}

Fluorescence spectra of solutions, blank, the inhibitor and the best system were recorded by using a Jasco-6300 spectrofluorometer.

\section{Scanning Electron Microscopic studies (SEM)}

The surface morphology measurements of the thin wire metal specimen were examined using Tescon, Vega3, and a USA computer controlled scanning electron microscope. The surface morphology was examined for the thin wire metal specimen in absence and in presence of the inhibitor system. The specimen immersed in the best system for a period of one day was removed, rinsed with double distilled water, dried and observed in a scanning electron microscope to examine the surface morphology.

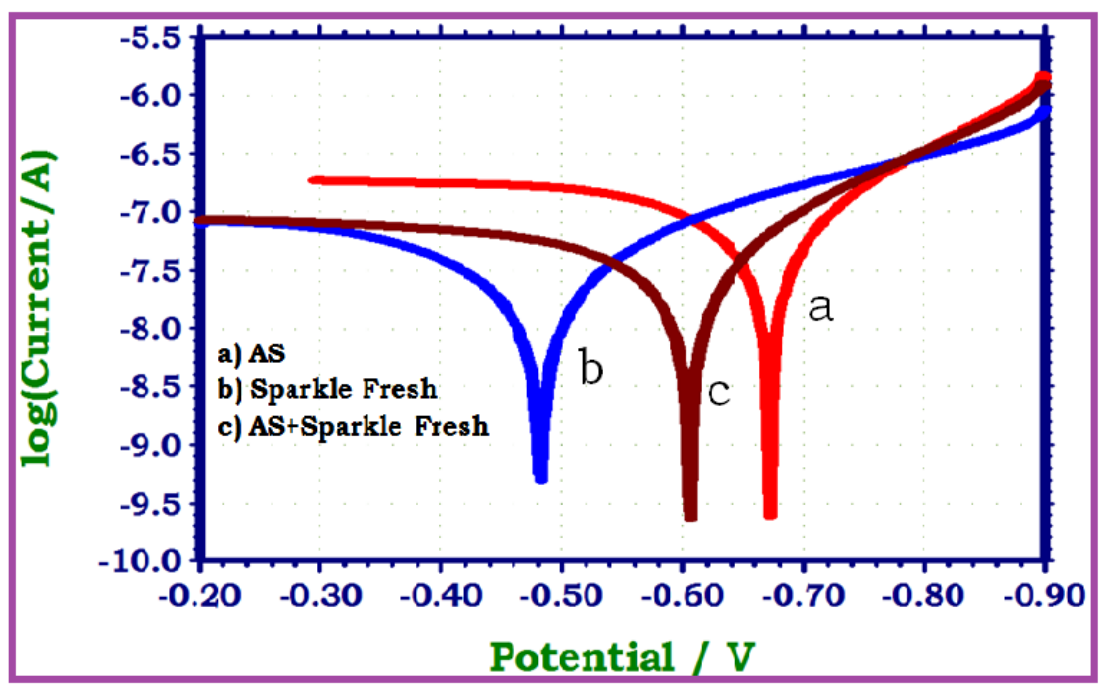

Figure 1. Polarization curves of SS 316L immersed in artificial saliva (AS) in the absence and presence of a sparkle fresh toothpaste. (a) Artificial saliva (AS); (b) Sparkle fresh (1\%); (c) AS + sparkle fresh (1\%). 
Energy Dispersive Analysis of $X$-rays (EDAX)

SEM imaging gives the morphological data for a sample; however, by using $\mathrm{X}$ ray spectroscopy in conjunction with SEM, the elemental composition can be determined. The elements present in a material are determined by an EDAX spectrum. An energy dispersive X-ray analyzer (EDAX) [Brucker, Nano, GMBH, Germany] unit attached to the SEM machine was used to carry out the elemental analysis of the metal surface.

\section{Result and discussion}

\section{Analysis of potentiodynamic polarization study}

The polarization curves of SS 316L immersed in various test solutions are shown in Fig. 1.

The corrosion parameters, namely, corrosion potential $\left(\mathrm{E}_{\mathrm{corr}}\right)$, Tafel slopes $\left(\mathrm{b}_{\mathrm{c}}=\right.$ cathodic; $b_{a}=$ anodic), linear polarization resistance (LPR) and corrosion current ( $\left.\mathrm{I}_{\text {corr }}\right)$ derived from polarization curves are given in Table 1.

Table 1. Corrosion parameters of SS 316L immersed in various test solutions obtained from the polarization study.

\begin{tabular}{|c|c|c|c|c|c|}
\hline System & $\begin{array}{c}\text { Ecorr }_{\text {corr }} \\
\text { mV vs. SCE }\end{array}$ & $\begin{array}{c}\mathbf{b}_{c} \\
\text { mV/decade }\end{array}$ & $\begin{array}{c}\mathbf{b}_{\mathbf{a}} \\
\text { mV/decade }\end{array}$ & $\begin{array}{c}\text { LPR } \\
\text { Ohm } \text { cm }^{2}\end{array}$ & $\begin{array}{c}I_{\text {corr }} \\
A / \mathbf{c m}^{2}\end{array}$ \\
\hline $\mathbf{A S}$ & -672 & 154 & 279 & 630154 & $6.872 \times 10^{-8}$ \\
\hline Sparkle Fresh & -606 & 149 & 316 & 1347241 & $3.272 \times 10^{-8}$ \\
\hline AS + Sparkle Fresh & -482 & 177 & 244 & 1813475 & $2.464 \times 10^{-8}$ \\
\hline
\end{tabular}

This observes that, when SS 316L is immersed in AS, the corrosion potential is $-672 \mathrm{mV}$ vs. SCE. The linear polarization resistance value is $630154 \mathrm{Ohm} \mathrm{cm}^{2}$. The corrosion current is $6.872 \times 10^{-8} \mathrm{~A} / \mathrm{cm}^{2}$. When SS $316 \mathrm{~L}$ is immersed in an aqueous solution of (1\%) sparkle fresh toothpaste, the corrosion potential is shifted to the noble side $(-606 \mathrm{mV}$ vs. SCE). The linear polarization resistance

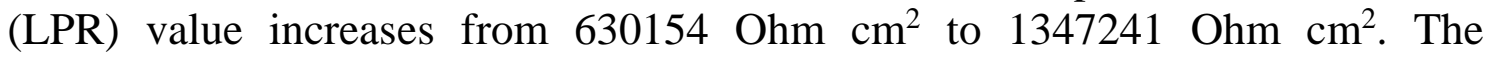
corrosion current decreases from $6.872 \times 10^{-8} \mathrm{~A} / \mathrm{cm}^{2}$ to $3.272 \times 10^{-8} \mathrm{~A} / \mathrm{cm}^{2}$. These observations indicate that the anodic reaction is predominantly controlled. A protective film is formed on the metal surface. Hence, the linear polarization resistance $(\mathrm{LPR})$ value increases and corrosion current $\left(\mathrm{I}_{\text {corr }}\right)$ decreases. The protective film may probably consist of complexes formed between stainless steel ions and the active principles of the toothpaste ingredients.

When SS 316L is immersed in an aqueous solution consisting of AS and the 1\% paste solutions, the corrosion potential is shifted to the anodic side $(-482 \mathrm{mV}$ vs. $\mathrm{SCE}$ ). Hence, it is inferred that the anodic reactions are predominantly controlled. Further, the linear polarization resistance (LPR) value increases from $630154 \mathrm{Ohm} \mathrm{cm}^{2}$ to $1813475 \mathrm{Ohm} \mathrm{cm}^{2}$. Corrosion current decreases from 6.872 $\mathrm{x} 10^{-8} \mathrm{~A} / \mathrm{cm}^{2}$ to $2.464 \times 10^{-8} \mathrm{~A} / \mathrm{cm}^{2}$. These observations indicate that the corrosion resistance of SS $316 \mathrm{~L}$ increases when it is immersed in AS containing aqueous solutions of the sparkle fresh toothpaste. 


\section{Analysis of AC impedance spectra}

The AC impedance spectra of SS 316L immersed in various test solutions are shown in Figs. 2, 3, 4 and 5.

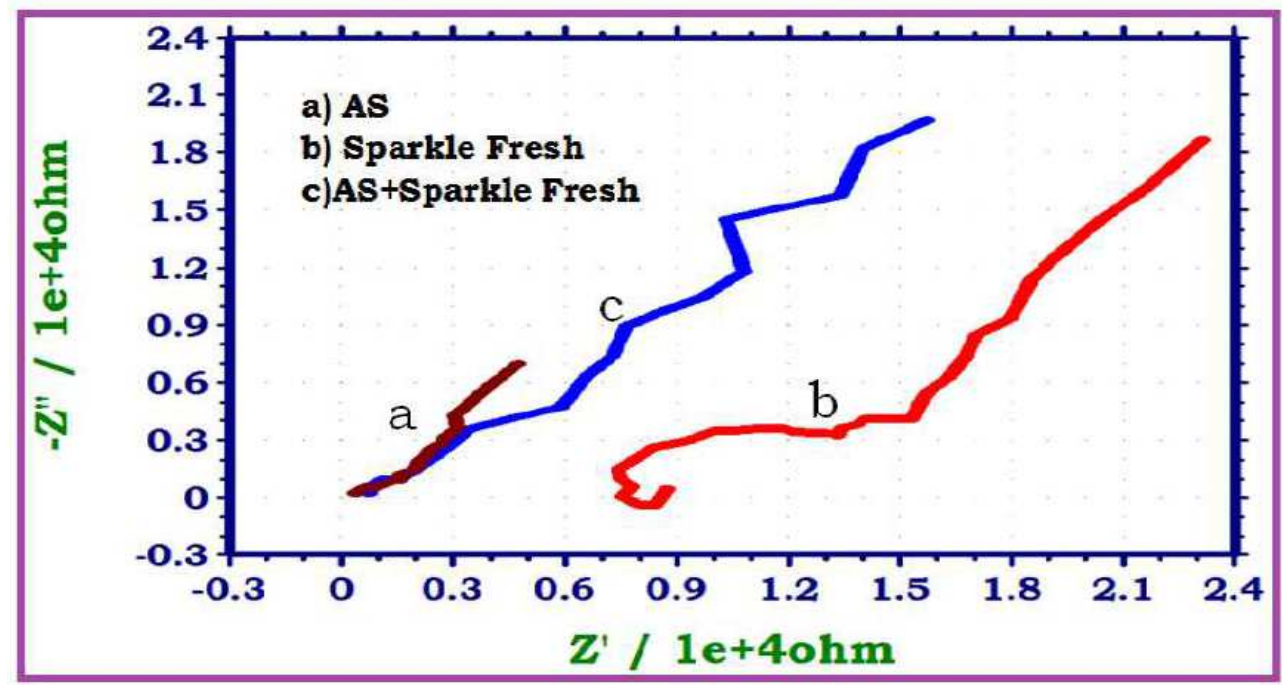

Figure 2. AC impedance spectra of SS 316L immersed in AS in the absence and presence of sparkle fresh toothpaste (Nyquist plots). (a) AS; (b) Sparkle fresh (1\%); (c) AS + sparkle fresh (1\%).

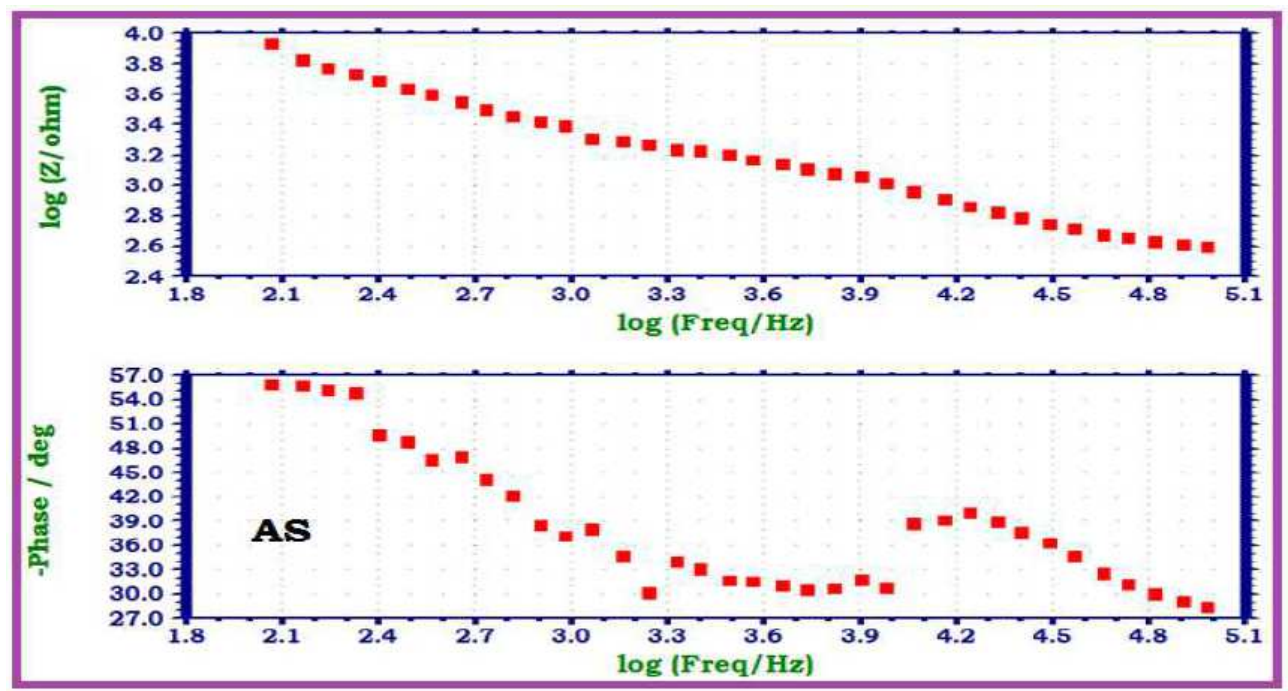

Figure 3. AC Impedance spectra of SS 316L immersed in (AS) (Bode plots).

The Nyquist plots are shown in Fig. 2. The Bode plots are shown in Figs. 3, 4 and 5. The corrosion parameters derived from these plots are shown in Table 2. 


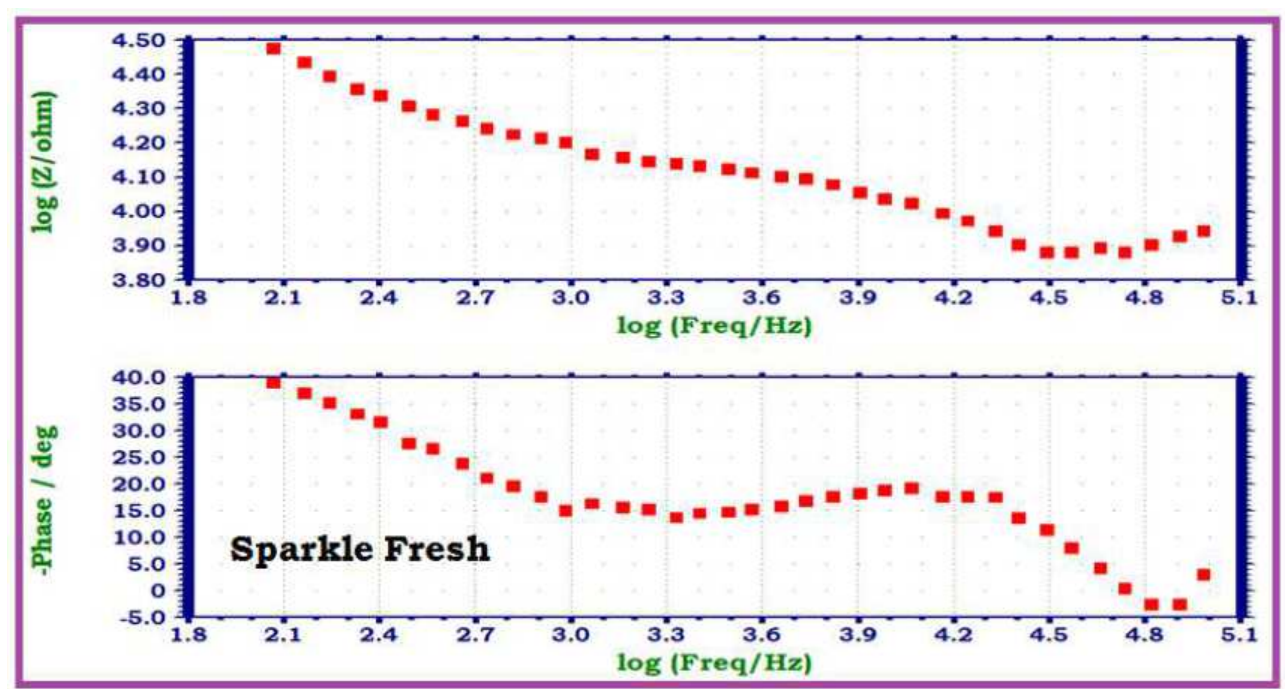

Figure 4. AC impedance spectra of SS 316L immersed in sparkle fresh (1\%) (Bode plots).

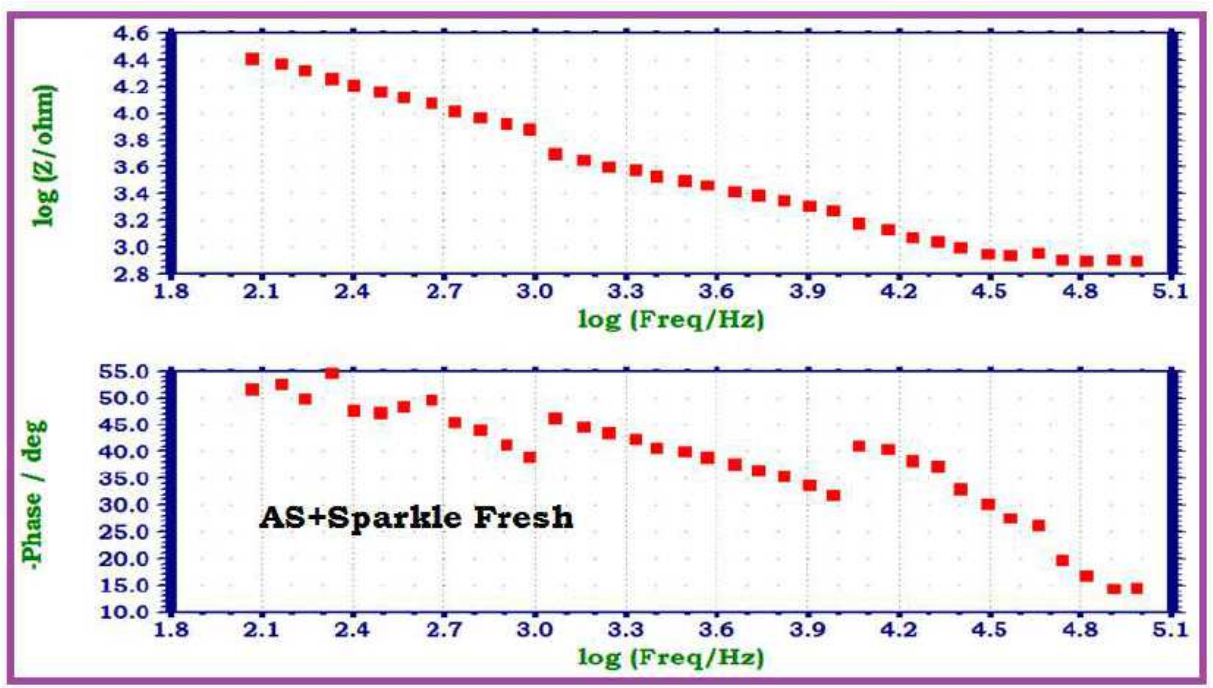

Figure 5. AC impedance spectra of SS 316L immersed in artificial saliva (AS) in the presence of a sparkle fresh toothpaste (1\%) (Bode plots).

Table 2. Corrosion parameters of SS 316L immersed in various test solutions obtained from AC impedance spectra.

\begin{tabular}{|l|c|c|c|}
\hline \multirow{2}{*}{ System } & \multicolumn{2}{|c|}{ Nyquist plot } & Bode plot \\
\cline { 2 - 4 } & $\boldsymbol{R}_{\mathbf{t}}$ & $\boldsymbol{C}_{\mathbf{d l}}$ & Impedance value \\
\hline AS & 439 & $11.598 \times 10^{-10}$ & 3.928 \\
\hline Sparkle fresh & 14380 & $3.5465 \times 10^{-10}$ & 4.473 \\
\hline AS + sparkle fresh & 14961 & $3.4088 \times 10^{-10}$ & 4.397 \\
\hline
\end{tabular}

When SS 316L is immersed in AS, the charge transfer resistance $\left(\mathrm{R}_{\mathrm{t}}\right)$ value is $4397 \mathrm{Ohm} \mathrm{cm}^{2}$, the double layer capacitance $\left(\mathrm{C}_{\mathrm{dl}}\right)$ value is $11.598 \times 10^{-10} \mathrm{~F} / \mathrm{cm}^{2}$ and the impedance $(\log \mathrm{z} / \mathrm{Ohm})$ value is 3.928 . When $\mathrm{SS} 316 \mathrm{~L}$ is immersed in aqueous solutions of (1\%) sparkle fresh toothpaste, the charge transfer resistance $\left(\mathrm{R}_{\mathrm{t}}\right)$ value increases from $4397 \mathrm{Ohm} \mathrm{cm}^{2}$ to $14380 \mathrm{Ohm} \mathrm{cm}^{2}$; the double layer capacitance value $\left(\mathrm{C}_{\mathrm{dl}}\right)$ decreases from $11.598 \times 10^{-10} \mathrm{~F} / \mathrm{cm}^{2}$ to $3.5465 \times 10^{-10}$ 
$\mathrm{F} / \mathrm{cm}^{2}$, and the impedance value (log $\mathrm{z} / \mathrm{Ohm}$ ) increases from 3.928 to 4.473 . These observations indicate that a protective film is formed on the metal surface when SS 316L is immersed in aqueous solutions of a sparkle fresh toothpaste. The protective film prevents the transfer of electrons from the metal surface to the bulk of the solutions. Hence, corrosion resistance increases and the rate of corrosion decreases. The protective film probably consists of stainless steel ions, and the active principle of the toothpaste's ingredients.

When SS 316L is immersed in AS containing an aqueous solution of sparkle fresh toothpaste, the charge transfer resistance $\left(R_{t}\right)$ value increases from 4397

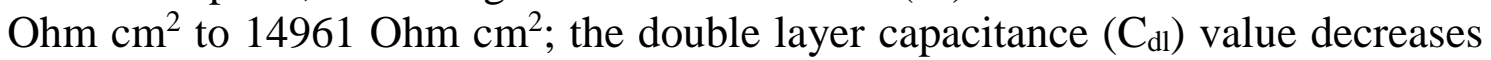
from $11.598 \times 10^{-10} \mathrm{~F} / \mathrm{cm}^{2}$ to $3.4088 \times 10^{-10} \mathrm{~F} / \mathrm{cm}^{2}$; and the impedance (log $\mathrm{z} / \mathrm{Ohm}$ ) value increases from 3.928 to 4.397 . It is inferred that, in presence of AS containing sparkle fresh toothpaste, the corrosion resistance of SS 316L increases.

\section{Analysis of $U V$-visible absorption spectra}

The UV- visible absorption spectrum is used to confirm the protective film formed on the metal surface. The UV- visible absorption spectrum of artificial saliva is shown in Fig 6(a). Peaks appear at $352 \mathrm{~nm}, 480 \mathrm{~nm}$ and $660 \mathrm{~nm}$.

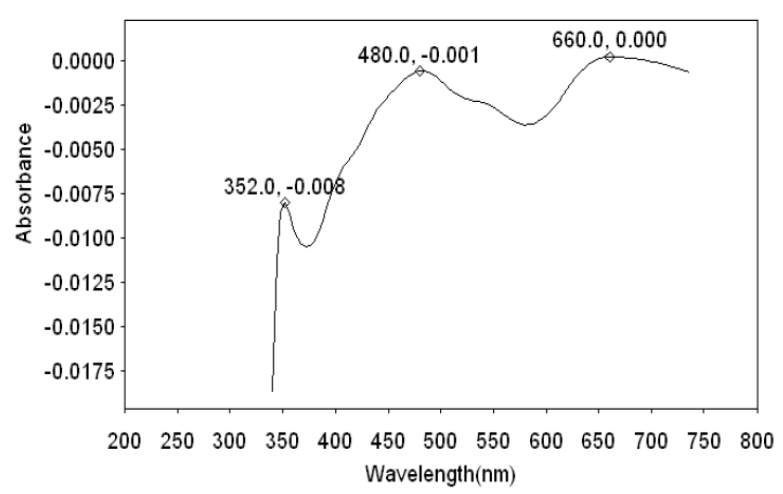

a)

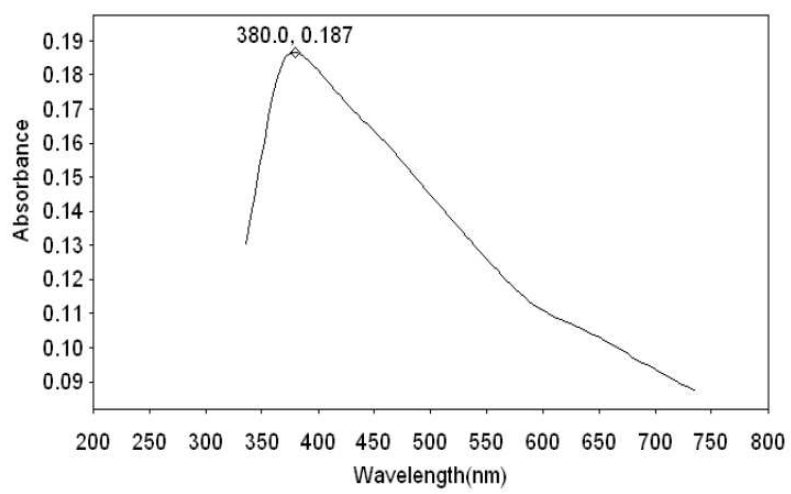

b)

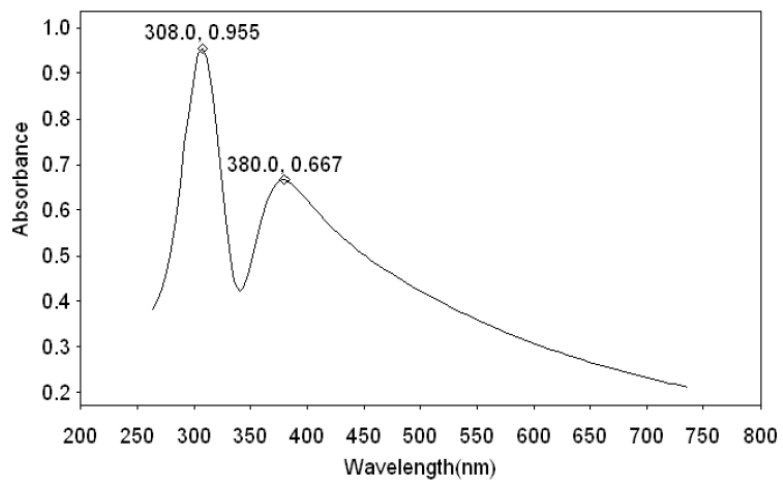

c)

Figure 6. UV-visible absorption spectra of: a) an AS solution; b) a solution containing sparkle fresh toothpaste; and c) a solution containing SS 316L + AS+ sparkle fresh toothpaste.

The UV- visible absorption spectrum of the toothpaste solution is shown in Fig 6(b). A peak appears at $380 \mathrm{~nm}$. The UV- visible absorption spectrum of the 
solution of AS toothpaste system, where in SS 316L has been immersed for one day, is shown in Fig 6(c).

A peak appears at $380 \mathrm{~nm}$. There is no shift in the position of $\lambda_{\max }$ of the toothpaste system. This indicates that the SS 316L alloy has not undergone corrosion in presence of the saliva and toothpaste system. Had there been corrosion, there would have been a shift in the position of $\lambda_{\max }$. The change in intensity at $380 \mathrm{~nm}$ may be attributed to the fact that there is no electronic transition because of the co-ordination of the active principles of the toothpaste's ingredients with the SS 316L alloy.

\section{Analysis of fluorescence spectra}

Fluorescence spectra are used to detect the presence of the metal-inhibitor complex formed on the surface of the SS 316L alloy. The fluorescence spectrum $\left(\lambda_{\mathrm{ex}}=300 \mathrm{~nm}\right)$ of AS is shown in Fig. 7(a). A peak appears at $378.5 \mathrm{~nm}$. The fluorescence spectrum $\left(\lambda_{\mathrm{ex}}=300 \mathrm{~nm}\right)$ of an aqueous solution of sparkle fresh toothpaste is shown in Fig. 7(b). Emission takes place at $381.5 \mathrm{~nm}$. SS 316L was immersed in an aqueous solution containing AS and the sparkle fresh toothpaste. A solution was obtained. The fluorescence spectrum $\left(\lambda_{\mathrm{ex}}=300 \mathrm{~nm}\right)$ of this solution is shown in Fig. 7(c).

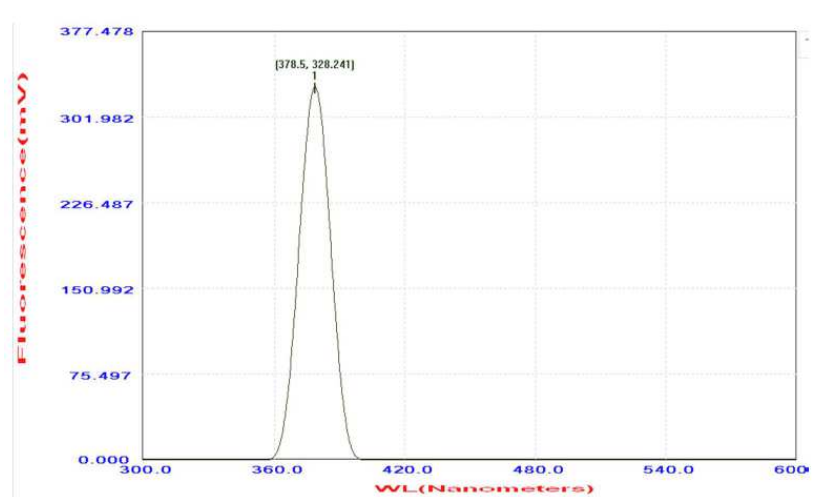

a)

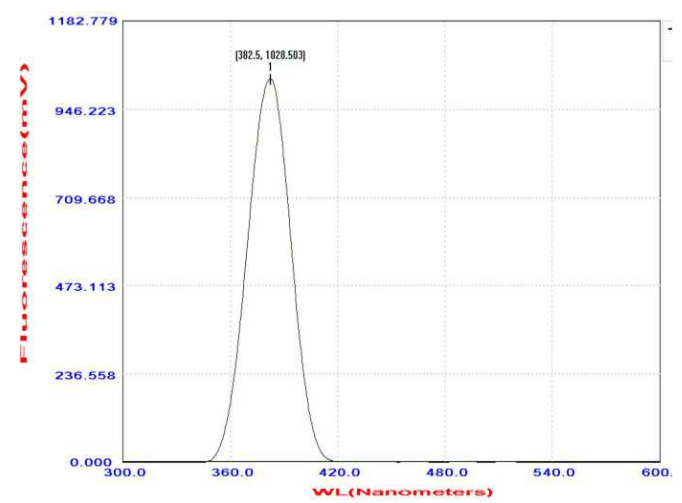

b)

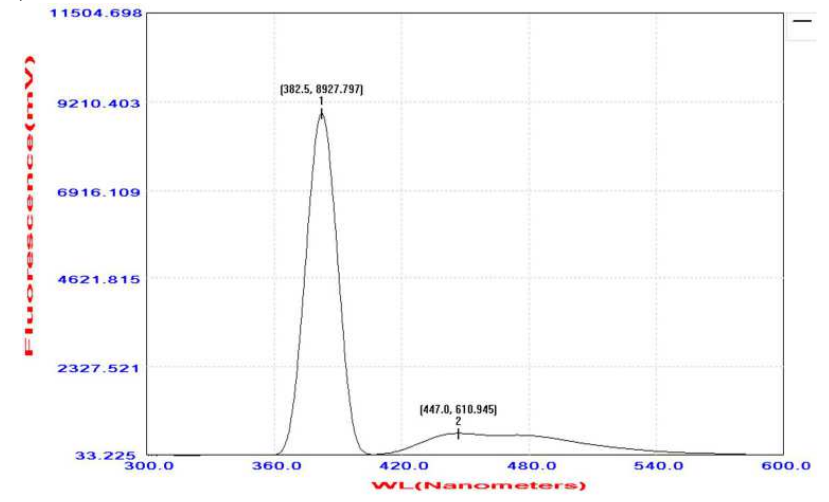

c)

Figure 7. Fluorescence spectra of: a) an AS solution; b) a solution containing sparkle fresh toothpaste; and c) a solution containing SS 316L + AS+ sparkle fresh toothpaste.

The peaks appear at $382.5 \mathrm{~nm}$ and $447.0 \mathrm{~nm}$. The shift in $\lambda_{\max }$ is not substantial. This indicates that SS $18 / 8$ has not undergone substantial corrosion in presence 
of AS and the toothpaste. The slight shift in the $\lambda_{\max }$ value may be due to the release of some $\mathrm{Cu}$ ions in this system. This indicates that a protective film is formed on the metal surface. There is UV-blue emission.

\section{Analysis of Scanning Electron Microscopy (SEM)}

SEM images for SS 316L alloy in absence and presence of the system are shown in Fig. 8 (a) and (b). The surface is found to be smooth only for pure polished metals; the system surface has become rough due to the presence of a film deposited on the metal surface. This protective film is due to the deposition of the active principles of the ingredients present in the toothpaste.

(a)

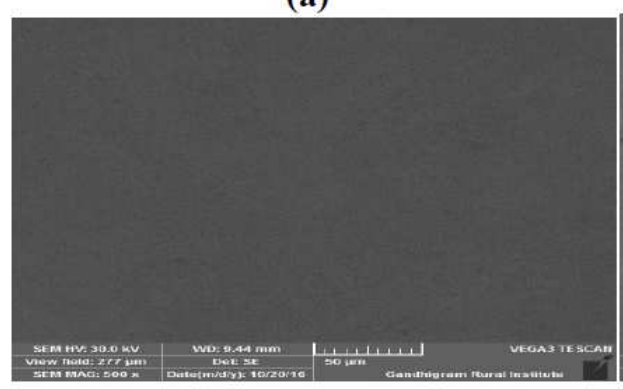

(b)

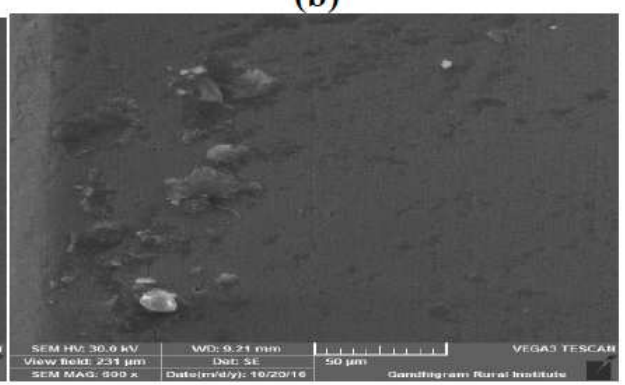

Figure 8. SEM images for an SS 316L alloy in absence and presence of the system (AS + sparkle fresh tooth paste). (a) Polished SS 316L. (b) Polished SS 316L immersed in AS containing sparkle fresh toothpaste.

\section{Energy Dispersive Analysis of $X$-rays (EDAX)}

The EDAX spectra are shown in Fig. 9 (a) and (b). It is seen from the EDAX spectra that $\mathrm{Fe}, \mathrm{Cr}, \mathrm{Ni}$ and $\mathrm{C}$ are present in both absence and presence of the inhibitor (Table 3 and 4). But the weight percentage of these elements has changed after immersion in the AS containing a sparkle fresh toothpaste. The weight percentage of $\mathrm{Fe}$ and $\mathrm{Cr}$ has increased as weight percentage of $\mathrm{C}$ decreases. The intensity of the peak of Fe is reduced as the active principles of the toothpaste's ingredients form a protective film on the metal surface, thus preventing the corrosion of the SS 316L alloy.

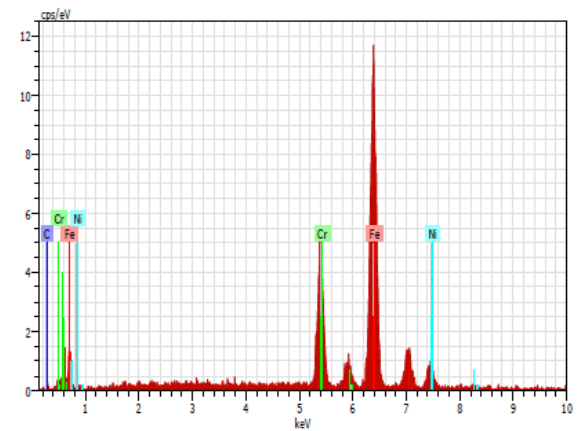

(a)

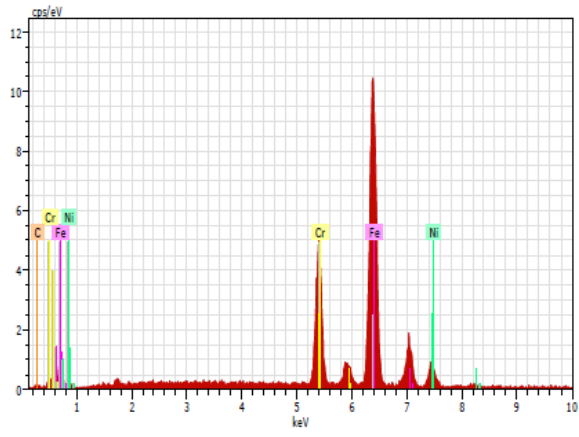

(b)

Figure 9. EDAX spectra of (a) polished SS 316L, and (b) polished SS 316L immersed in AS containing a sparkle fresh toothpaste. 
Table 3. Spectrum of the SS316L alloy.

\begin{tabular}{|c|c|c|c|c|}
\hline El & $\begin{array}{c}\text { AN Series unn. } \\
{[w t . \%]}\end{array}$ & $\begin{array}{c}\text { C norm. } \\
{[w t . \%]}\end{array}$ & $\begin{array}{c}\text { C Atom. } \\
\text { [at. \%] }\end{array}$ & $\begin{array}{c}\text { C Error } \\
\text { (1 Sigma) [wt. \%] }\end{array}$ \\
\hline Fe 26 K-series & 68.38 & 69.48 & 60.38 & 2.03 \\
\hline Cr 24 K-series & 18.17 & 18.47 & 17.24 & 0.66 \\
\hline Ni 28 K-series & 8.06 & 8.19 & 6.77 & 0.48 \\
\hline C 6 K-series & 3.80 & 3.86 & 15.61 & 3.48 \\
\hline Total & $\mathbf{9 8 . 4 1}$ & $\mathbf{1 0 0 . 0 0}$ & $\mathbf{1 0 0 . 0 0}$ & \\
\hline
\end{tabular}

Table 4. Spectrum of SS 316L + AS + sparkle fresh toothpaste.

\begin{tabular}{|c|c|c|c|c|}
\hline EI & $\begin{array}{c}\text { AN Series unn. } \\
{[w t . \%]}\end{array}$ & $\begin{array}{c}\text { C norm. } \\
\text { [wt.\%] }\end{array}$ & $\begin{array}{c}\text { C Atom. } \\
\text { [at.\%] }\end{array}$ & $\begin{array}{c}\text { C Error } \\
\text { (1 Sigma) [wt.\%] }\end{array}$ \\
\hline Fe 26 K-series & 67.54 & 72.00 & 68.57 & 1.84 \\
\hline Cr 24 K-series & 17.98 & 19.16 & 19.60 & 0.57 \\
\hline Ni 28 K-series & 7.27 & 7.75 & 7.02 & 0.33 \\
\hline C 6 K-series & 1.02 & 1.09 & 4.81 & 1.13 \\
\hline Total & $\mathbf{9 3 . 8 1}$ & $\mathbf{1 0 0 . 0 0}$ & $\mathbf{1 0 0 . 0 0}$ & \\
\hline
\end{tabular}

\section{Conclusions}

In presence of a sparkle fresh toothpaste, corrosion resistance of the SS 316L alloy increases. Hence, it is recommended that people implanted with orthodontic wires made of SS 316L alloy use sparkle fresh toothpaste to clean their teeth without any hesitation. So, dentists can recommend this toothpaste to their patients.

\section{Acknowledgements}

The authors are thankful to their respective departments for the help and encouragement to carry out this research.

\section{References}

1. Dongre, Choudaha S. Int J Innov Eng Res. 2016;6:1.

2. Roach M. Dent Clin North Am. 2007;51:603.

3. Hermawan H, Ramdan D, Djuansjah JRP. Intech. 2011;17:411.

4. Wensley A. Mater Sci Res Innov. 2015.

5. Walker MP, White RJ, Kula KS. Am J Orthod Dentof Orthop. 2005;127:662.

6. Kaneko K, Yokoyama K, Moriyama K, et al. Angle Orthodontist. 2004;74:487.

7. Yokoyama K, Kaneko K, Ogawa T, et al. Biomaterials. 2004;26:101.

8. Schiff N, Grosgogeat B, Lissac M, et al. Biomaterials. 2004;25:4535.

9. Ogawa T, Yokoyama K, Asaoka K, et al. Biomaterials. 2004;25:2419.

10. Kaneko K, Yokoyama K, Moriyama K, et al. Biomaterials. 2003;24:2113.

11. McCann HC. Inorganic components of salivary secretions in art and science of dental caries research. Harris RS, editor. New York: Academic Press; 1968. p. 55-70. 
12. House K, Sernetz F, Dymock D, et al. Am J Orthodontics Dentofacial Orthopedics. 2008;133:584.

13. Unal, Zor S, Atapek H. Mater Sci. 2012;47:830.

14. Hancu V, Comaneanu RM, Coman C, et al. Rev Chim (Bucharest). 2014;65:706.

15. Rajendran S, Uma V, Krishnaveni A, et al. Arab J Sci Eng. 2009;34:147.

16. S. Rajendran S, Paulraj J, Rengan P, et al. J Dent Oral Hug. 2009;1:1.

17. Meyer M. Corros Sci. 1977; 17:971.

18. Brett MAC, Muresan I. Eng Mater. 2002;230-232:459. 